\title{
Barriers to scaling sustainable land and water management in Uganda: a cross-scale archetype approach
}

\author{
Luigi Piemontese $^{1}$, Rick Nelson Kamugisha $^{2,3}$, Joy Margaret Biteete Tukahirwa $^{2}$, Anna Tengberg ${ }^{4,5}$ Simona Pedde $^{6}$ and Fernando $^{\text {Sim }}$

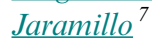

\begin{abstract}
In African small-scale agriculture, sustainable land and water management (SLWM) is key to improving food production while coping with climate change. However, the rate of SLWM adoption remains low, suggesting a gap between generalized SLWM advantages for rural development across the literature, and the existence of context-dependent barriers to its effective implementation. Uganda is an example of this paradox: the SLWM adoption rate is low despite favorable ecological conditions for agriculture development and a large rural population. A systemic understanding of the barriers hindering the adoption of SLWM is therefore crucial to developing coherent policy interventions and enabling effective funding strategies. Here, we propose a cross-scale archetype approach to identify and link barriers to SLWM adoption in Uganda. We performed 80 interviews across the country to build cognitive archetypes, harvesting stakeholders' perceptions of different types of barriers. We complemented this bottom-up perspective with a spatial archetype analysis to contextualize these results across different social-ecological regions. We found poverty trap, overpopulation, risk aversion, remoteness, and post-conflict patriarchal systems as cognitive archetypes that synthesize the different dynamics of barriers to SLWM adoption in Uganda. Our results reveal both specific and cross-cutting barriers. Ineffective extension services emerges as a ubiquitous barrier, whereas gender inequality is a priority barrier for large supported farms and farms in drier lowlands in northern Uganda. The combination of cognitive and spatial archetypes proposed here can help to overcome ineffective "one-size-fits-all" solutions and support context-specific policy plans to scale up SLWM, rationing resources to support sustainable intensification of agriculture.
\end{abstract}

Key Words: archetype analysis; barriers to adoption; sustainability science; sustainable land and water management; Uganda

\section{INTRODUCTION}

Inadequate food production affects the livelihoods of millions of people globally and is the top national and international challenge for achieving sustainable development goals (Conceição et al. 2016, Pérez-Escamilla 2017). In the subsistence farming systems of sub-Saharan Africa, low land and water productivity is driven by land degradation; low access to irrigation infrastructure; and limited access to farm inputs, markets, and technologies (Pimentel 2006, Sietz and Van Dijk 2015). Land degradation is further exacerbated by climate change, which is shifting seasonal precipitation patterns, increasing the frequency of droughts and extreme precipitation events (Zika and Erb 2009). Sustainable land and water management (SLWM) practices can play a key role in coping with hydroclimatic changes by determining the amount and frequency of precipitation reaching crops, maintaining and sustaining soil health (Piemontese et al. 2019). In most of the rainfed agriculture of sub-Saharan Africa, 50-70\% of precipitation is lost as soil evaporation or surface runoff (i.e., not contributing to plant growth), undermining crop production and triggering soil erosion (Wani et al. 2009).

Generally, SLWM has the primary aim of enhancing soil water productivity, limiting surface runoff, and maximizing water storage in the soil while preserving its long-term environmental functions (Liniger et al. 2011). Typical examples of SLWM practices are trenches, terraces, and check dams, which are usually implemented along contour lines in steep terrain to slow down precipitation runoff and increase infiltration, as well as mulching (covering soil), often with organic matter, to limit water loss from evaporation and to build soil structure. These practices are often combined to increase water productivity at the farm scale, with long-term positive effects on food security and income (Howie 2008, Bouma et al. 2016). To achieve the potential to meet sustainable development goals, SLWM practices need to be adopted by a critical mass of farmers and widely replicated and extended across geographic space with the support of national, regional, and international policies (Thomas et al. 2018) using a process commonly known as scaling (Howie 2008). A critical step in the scaling process is the identification and thorough understanding of barriers to SLWM (Wigboldus et al. 2016).

Scaling up SLWM is particularly relevant for Uganda, where $80 \%$ of the population are subsistence smallholder farmers and the agro-climatic conditions are generally favorable for agriculture (Fowler and Rockstrom 2001, Banadda 2010). For instance, in the Kabale district, conservation agriculture, including the use of cover crops, green manure, and mulch, has increased cereal yields by $50-100 \%$ (Pretty 1999, Ellis-Jones and Tengberg 2000), and trenches and terraces, implemented on steep landscapes, have increased crop quality and production by at least $20-50 \%$ (WOCAT 2019). In the northern regions of Uganda, agroforestry and mulching have been commonly implemented to limit evaporation, leading to a 10 -fold increase in banana production (WOCAT 2019).

Despite the documented successes, scaling SLWM remains a challenge in Uganda (Hart and Mouton 2005). Local studies have

${ }^{1}$ Stockholm Resilience Centre, Stockholm University, Sweden, ${ }^{2}$ Uganda Landcare Network (ULN), Uganda, ${ }^{3}$ College of Agriculture and Environmental Sciences (CAES), Department of Extension and Innovation Studies, Makerere University, Kampala, Uganda, ${ }^{4}$ Swedish Water House | Stockholm International Water Institute (SIWI), Sweden, ${ }^{5}$ Lund University Centre for Sustainability Studies (LUCSUS), Lund University, Sweden, ${ }^{6}$ Soil Geography and Landscape Group, Wageningen University and Research, The Netherlands, ${ }^{7}$ Department of Physical Geography and Quaternary Geology, Stockholm University, Sweden 
identified barriers related to farm characteristics (e.g., farm size, location, and slope; Kassie et al. 2011, Mugisha and Alobo 2012), household conditions (e.g., household size, education, and occupation; Nkonya 2002, Ebanyat et al. 2010), and the socioeconomic context (e.g., access to market, gender inequality, and agricultural extension services coverage; Mwangi and Kariuki 2015, Aduwo et al. 2019). Even though the barriers to adoption of SLWM have been studied and reported for individual cases, their lack of relation to the broader geographical context and the lack of focus on causes and effects of existing barriers provide only a partial and fragmented understanding of the problem, bringing uncertainty about the interventions needed to facilitate the adoption and scaling of SLWM (Sietz and Van Dijk 2015, Wigboldus et al. 2016). In fact, policy instruments and largescale funding are guided by the national understanding of both the problems and solutions to land degradation (Sietz and Van Dijk 2015), and a lack of clear policy and legal frameworks can lead to the failure of government efforts (Ntale et al. 2005). If the manifold problems arise at the local scale but the solutions are provided top-down from standardized national plans, the lack of system perspective impedes the development of an enabling environment for successful implementation of SLWM (Anderson and Feder 2004, Ampaire et al. 2015, Tengberg and Valencia 2018). However, finding the best level of generalization that allows the capture of local differences while generating insights applicable to broader areas is a major challenge.

Here, we use archetype analysis to provide a system understanding of the barriers to scaling SLWM by identifying recurrent barriers across different social-ecological contexts in Uganda. Archetype analysis is used in sustainability science to identify patterns of similar conditions with the aim of supporting the scaling of sustainability solutions (Eisenack et al. 2019, Sietz et al. 2019). We propose a multimethod approach combining cognitive archetypes, which provide insights on social-ecological dynamics based on stakeholders' perceptions (Karrasch et al. 2019), with spatial archetypes, which delineate areas of generalizability for such dynamics. The results can be used by local and national policy makers to develop context-specific plans to scale up SLWM, thus rationing resources to support wide adoption and speeding the transition to sustainable agriculture.

\section{DATA AND METHODS}

\section{Methodological approach: archetype analysis}

We use archetype analysis to identify complex barriers to the scaling of SLWM across the diverse social-ecological contexts of Uganda. In general, archetype literature defines two major types of archetypes based on their meaning and use: building blocks and typology of cases (Oberlack et al. 2019). Archetypes as building blocks can be used to identify and describe specific processes and mechanisms, which can be combined (as building blocks) to explain the complexity of a single case (Oberlack et al. 2019). In contrast, typology of cases aims at identifying common patterns across a number of cases that are generally suited to delineate spatial archetypes such as individual districts with similar social-ecological patterns (Václavík et al. 2013, Sietz et al. 2017, Rocha et al. 2020). Here, we use cognitive archetypes as building blocks to provide insights into social-ecological dynamics hindering the adoption of SWLM within different spatial archetypes, which delineate potential areas of generalizability of such dynamics.

\section{Analytical framework}

The two different forms of archetype present common methodological steps such as attribute selection, data collection, and data analysis (Fig. 1). A key component in the delineation of archetypes is the set of attributes that is used to compare cases and assess their degree of similarity. We used two sets of cases, i.e., interviews and districts, and their two corresponding sets of attributes, cognitive and spatial attributes, respectively. In general, attributes selection can be guided by qualitative literature review (Václavík et al. 2013, Sietz et al. 2017), grounded in existing theories (Oberlack et al. 2019, Rocha et al. 2020), or derived by inductive bottom-up knowledge (Karrasch et al. 2019). We used the last approach to limit the biases of pre-existing theories, and we built on purely empirical knowledge. For the spatial attributes, we used a meta-analysis based on frequency of case-based research in Uganda. For the cognitive attributes, we used a stakeholder workshop.

Fig. 1. Analytical framework showing the analytical steps and methods used to delineate cognitive and spatial archetypes.

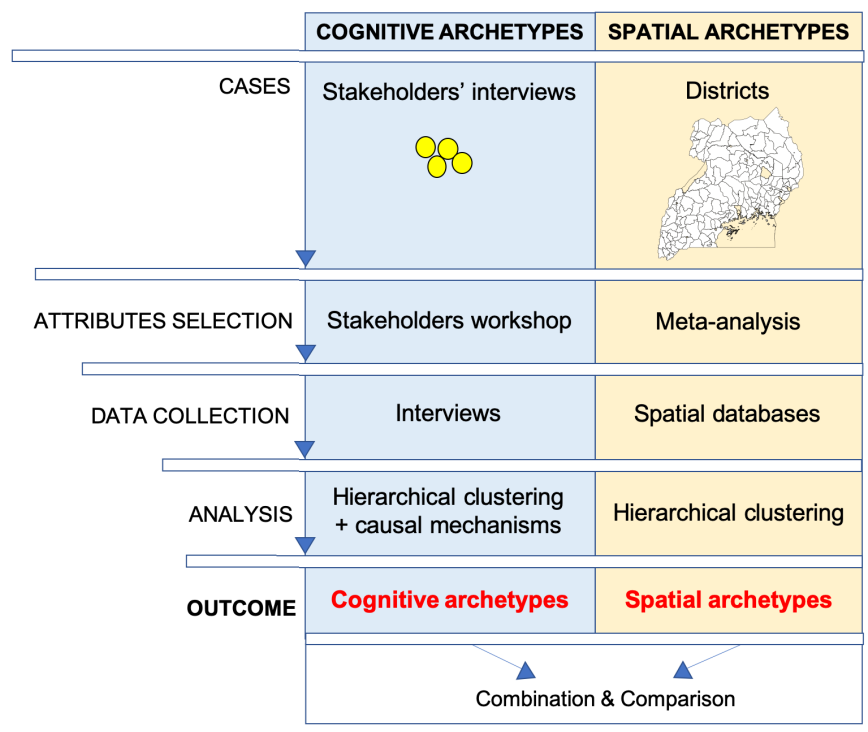

The final analytical step involves the combination and comparison of the two forms of archetypes to evaluate how cognitive and spatial archetypes can reveal complementary information that jointly explain the barriers to adoption of SLWM. Apart from the abovementioned trenches, terraces, and mulching, the range of SLWM practices considered here include other practices aimed at decreasing soil erosion such as check dams and grass bands, and practices for soil rehabilitation and productivity improvement such as organic manure, zero grazing, intercropping, and agroforestry.

\section{Cognitive archetypes}

Cognitive attributes selection: stakeholder workshop

The set of attributes used to generate the cognitive archetypes of barriers builds on the workshop that took place during the conference "Uganda Land Care Conference and Awards", held in Kabale (southwestern Uganda) on 28 November 2019. The workshop was a 1-h break-out group discussion with 40 attendees 
Fig. 2. Map showing the distribution of the interviews in Uganda and stakeholder characteristics for each district. Municipalities (in grey) were excluded from analysis because they represented non-rural contexts. Pink $=$ disticts where interviews were performed.

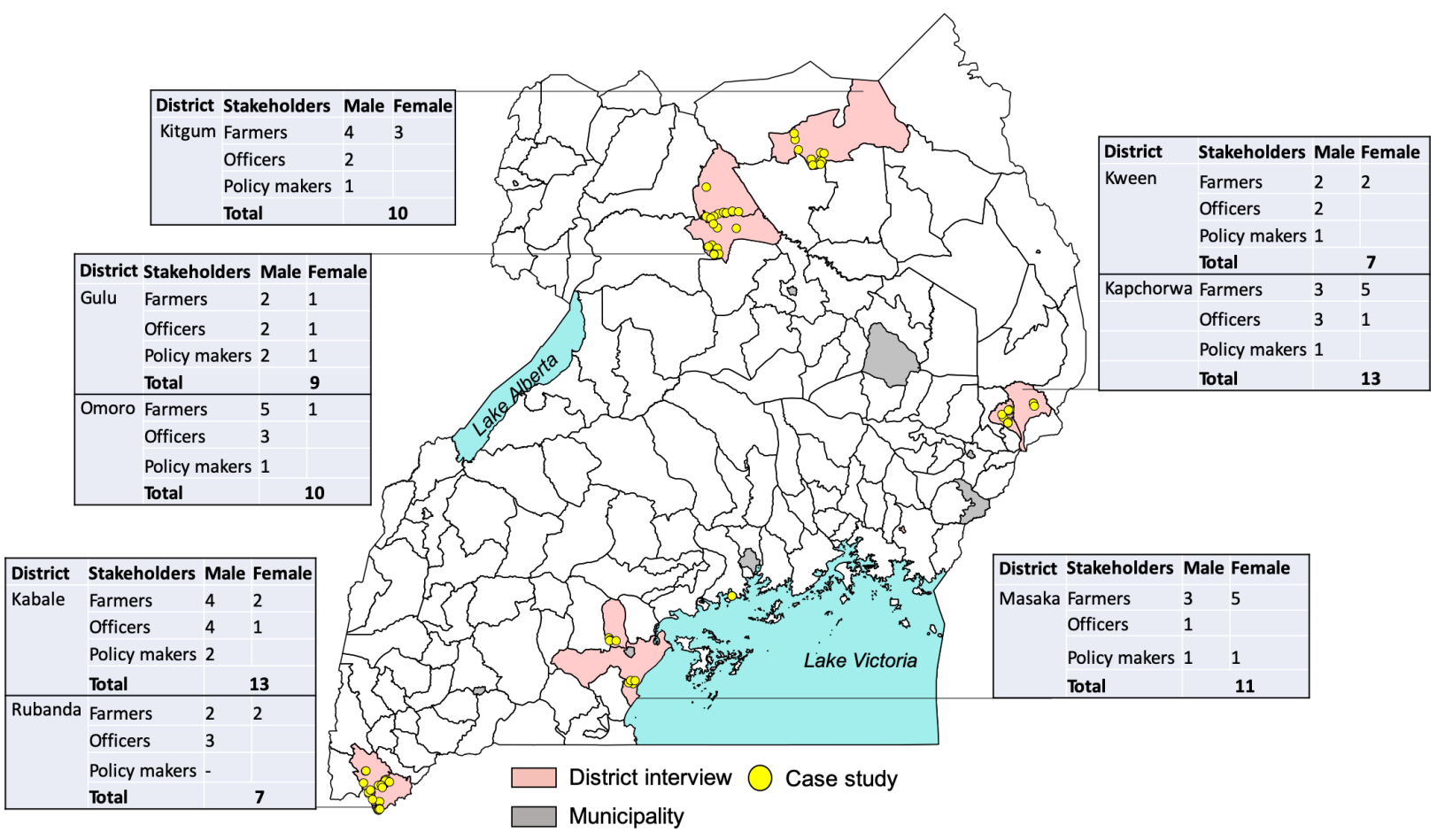

from different backgrounds (i.e., farmers, private sector, policy makers, researchers, and agricultural officers). We guided the discussion around the topic "barriers to upscaling SLWM in Uganda". The discussion started by listing the barriers to scaling up SLWM in Uganda, followed by a debate about the relative importance of different barriers depending on the geographical context. The workshop served to gain a system understanding of the type and geographical diversity of barriers, as perceived by the different groups of stakeholders, and to identify a set of barriers to be ranked by stakeholders in interviews following the workshop. This process resulted in a final set of 18 cognitive attributes (Table 1).

\section{Cognitive data collection: interviews and ranking of cognitive attributes}

The interviews were designed to collect quantitative data on the priority barriers using ranking and qualitative data related to the causal mechanisms behind different configurations of barriers as perceived by the stakeholders. We performed 80 interviews in the four macro-regions of Uganda to gain a comprehensive picture at the country scale during fieldwork between 21 November and 20 December 2019 (Fig. 2). The data collection process was designed in collaboration with the Uganda Landcare Network, a national landcare platform that fosters SLWM in Uganda with an extensive network of $>600$ members. Interviewees included farmers, local and national government officers, and policy makers involved in the uptake and dissemination of SLWM practices and identified within the Uganda Landcare Network. We included perspectives from both women and men when possible.
Table 1. Lists of cognitive and spatial attributes. The first five lines contain the cognitive and spatial attributes used in the uncertainty analysis because of their direct comparability.

\begin{tabular}{ll}
\hline \hline Cognitive attribute & Spatial attribute \\
\hline Land fragmentation & Farm size \\
Women empowerment & Gender gap \\
Ineffective agricultural extension & Access to agricultural extension \\
services & services \\
Lack of input or credit & Access to credit \\
Poverty & Rural poverty \\
Lack of awareness of sustainable & Precipitation \\
land and water management & \\
practices & \\
Limited farming skills & Temperature \\
Resistance to change & Slope \\
Lack of interest & Elevation \\
Unpredictable weather & Household size \\
Storms & Farmer organizations \\
Drought & Livestock \\
Pests and diseases & Remoteness \\
Weak law enforcement & Education \\
Uncontrolled bush fire & \\
Population growth & \\
Land tenure & \\
Conflicts & \\
\hline &
\end{tabular}

During the interviews, respondents were first asked what kind of SLWM practices they were implementing and how they came to practice SLWM. The interviews continued with follow up 
questions about the difficulties that respondents encountered during the adoption phase and the benefits that they observed. The interviews ended with ranking the five most relevant barriers to adoption of SLWM according to respondents' experiences, with 1 as the most relevant barrier (i.e., highest priority) and 5 as the fifth most relevant barrier, selected from the 18 cognitive attributes that were identified during the workshop.

To obtain reliable answers, we approached the interviewees with the assistance of a person with a deep understanding of the local conditions and connections with farmers (e.g., local extension workers, champion farmers, and researchers). Upon agreement, farmer respondents were interviewed only if they had used any type of SLWM practice within the most recent 2-yr period and had knowledge about constraints and barriers to use of SLWM practices. We selected farmers who adopted SLWM because they have the widest understanding of the barriers, having faced them and managed to overcome them (Fig. 2).

Identifying cognitive archetypes: hierarchical cluster analysis and causal mechanisms

We used cluster analysis to analyze both forms of archetype. Cluster analysis is a statistical method that group objects with similar attributes into exclusive clusters (Janssen et al. 2012). Clustering is a common approach to identify patterns across complex social-ecological systems and is often used in archetype analysis (Sietz et al. 2019). We used hierarchical clustering, which is commonly used in studies of social-ecological archetypes (Rocha et al. 2020).

Because the barrier ranks are categorical data (from 1 to 5), we performed hierarchical clustering using the Bray-Curtis dissimilarity measure (Ricotta and Podani 2017). We used the NbClust function in R (Charrad et al. 2014) to guide the first selection of clusters. NbClust is a function that computes 30 indices, including visual and numerical criteria, to suggest the optimal number of clusters based on the majority rule (i.e., number of clusters suggested by the majority of indices). For the sake of building meaningful archetypes, we further inspected the proposed optimal number of clusters to make sense of the statistical clustering with the qualitative data from the fieldwork. The qualitative insights that supported the interpretation of the clusters (names and meanings) were drawn from qualitative methods such as participant observation, field notes, and interview extracts (Schatzman and Strauss 1973, Hirschman 1986, Spradley 2016). We used field notes to identify the interviews with the richest explanation of the key causal dynamics and personal insights into how different barriers collectively characterize the overall gap in SLWM adoption.

\section{Spatial archetypes}

\section{Spatial attributes selection: meta-analysis}

We performed a meta-analysis of scientific literature focusing on the adoption of SLWM in Uganda to select relevant spatial indicators that were later used to build the spatial attributes. We did not specifically code the term "land and water management" because it does not traditionally belong to the jargon of local case studies. Instead, we coded for specific SLWM practices, using the following combination of search terms: "adopt*" AND ("soil and water conservation" OR "climate-smart agriculture" OR "*water harvesting" OR "management practices") AND "Uganda".
We found 24 papers, from which we identified 45 potential attributes (Table A1.1). We only selected attributes mentioned in at least three papers, except for "agro-climatic conditions", which only appeared twice. We included agro-climatic conditions through the proxies of "precipitation" and "temperature", otherwise biophysical conditions would be underrepresented.

We excluded the attribute "age", because it is too generic for spatial district-level analysis, and the attributes "land tenure/ownership" and "distance of farm to house" because of the unavailability of this information at the district level in Uganda. For the specific case of "farm income", we used the proxy of "rural poverty" because it is more inclusive by embracing "capital" and "cash". For "slope/location", we used "elevation" above sea level. Finally, we used the gap in education attainment between men and women, calculated in years, as a proxy for the more complex gender gap issue. The final set of 13 spatial attributes is listed in Table 1.

\section{Spatial data collection: data sets}

We gathered spatial data on the 13 spatial attributes to represent the distribution of social-ecological characteristics and barriers to SLWM in the different districts of Uganda (Fig. 3). We used the level-two Ugandan administrative boundaries from Global Administrative Areas (2012) as units of analysis. All spatial data were averaged at the district level. Uganda has 162 districts, which are commonly classified as counties $(N=142)$ or municipalities $(N$ $=20$ ); we excluded municipalities from our analysis because we focused on rural areas. The attributes were computed using data from different sources, including global raster databases (e.g., education attainment and total tropical livestock units) and tables compiled by national statistical reports (e.g., farmer organizations and extension services). The complete list of spatial attributes, with detailed description and data sources, are available in Table A1.2.

Identifying spatial archetypes: hierarchical cluster analysis

For spatial archetypes, we used the same hierarchical analysis as for cognitive archetypes. However, we first normalized the attributes by scaling them to zero mean and unit variance so that variables were of comparable magnitude and outlier effects were removed (Václavík et al. 2013). We also used a different dissimilarity measure, Ward's method (Ward 1963), as previously used for identifying spatial archetypes (Piemontese et al. 2020). We then used the NbClust function to select the optimal number of clusters.

\section{Comparison between cognitive and spatial attributes}

Our final step was to compare the archetypes. This process allowed us to assess the level of agreement between the two different sets of data (perception and spatial data). We used the results to guide the interpretation of the overall generalizability of local insights for larger areas.

Five pairs of attributes within the cognitive and spatial archetypes were comparable because they related to similar concepts: (1) "farm size" and "land fragmentation", (2) "gender gap" and "women empowerment", (3) "access to credit" and "lack of inputs/ credit", (4) "agricultural extension services coverage" and "ineffective agricultural extension services", and (5) "rural poverty" and "poverty" (Table 1). For instance, understanding whether the perception of land fragmentation (cognitive attribute) agrees with regional average farm size (spatial attribute) can indicate how much of stakeholders' perceptions are well captured 
Fig. 3. Maps showing spatial attributes of the barriers to sustainable land and water management adoption in Uganda at the district level. A detailed description of these attributes is available in Table A1.2.

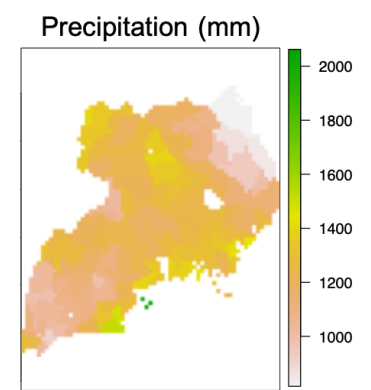

Access to credit (\%)

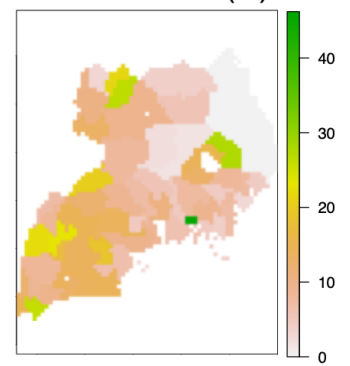

Remoteness (minutes)

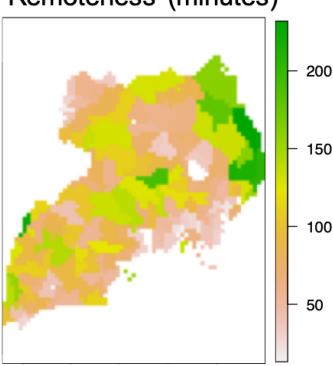

Elevation $(m)$

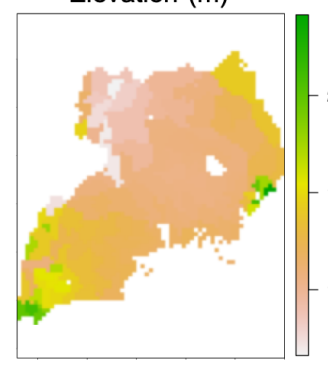

Houshold size (n)

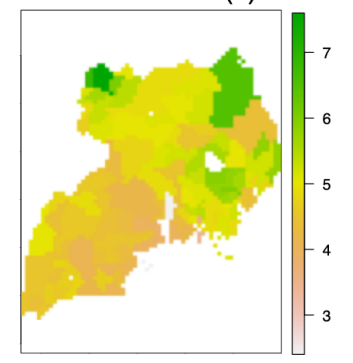

Gender gap (years)

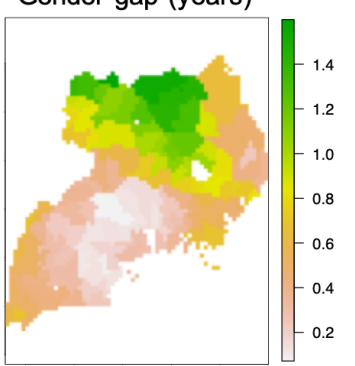

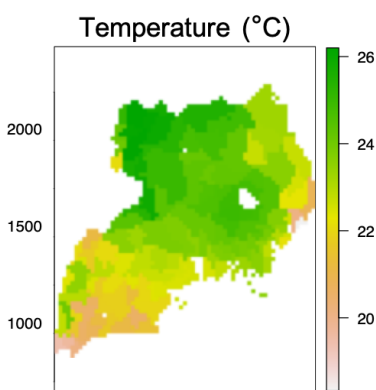

Rural poverty (population/km2)

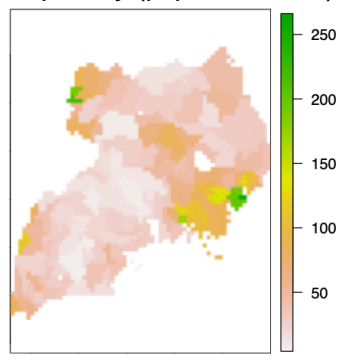

Education (years)

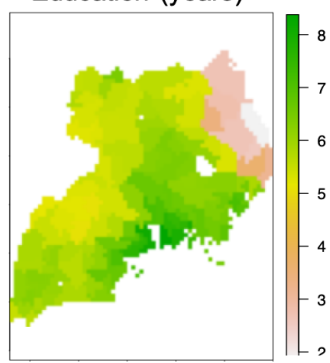

Farmers organizations (nr./population)

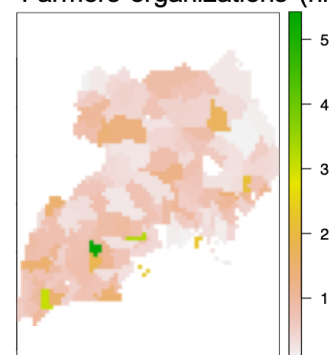

Livestock (TLU)

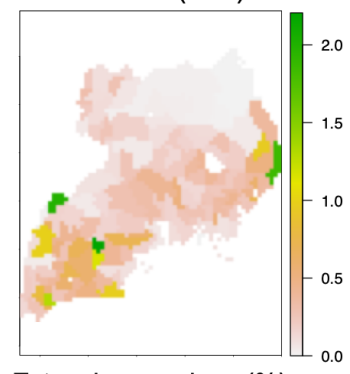

Extension services (\%)

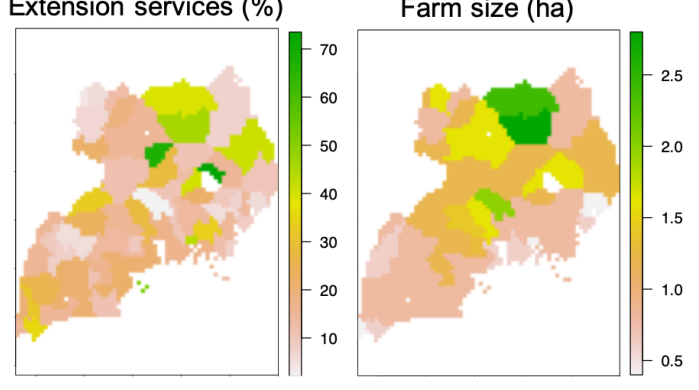

by the district-level data. The perception data underlying the cognitive attribute are ranks (i.e., priority level 1-5), whereas the spatial data are quantitative measures of different units (e.g., farm size in hectares). To make the two sets of data comparable, we first calculated a dimensionless score for the cognitive attributes (Priority Score), then we normalized and centered the Priority Score and the spatial attributes on their mean, similar to the preprocessing performed for the hierarchical clustering described previously.

To obtain the Priority Score, we first gave each priority level $\left(P_{\mathrm{i}}\right)$ a score, with the highest priority (1) given 5 points and the least important attribute (5) given 1 point. Second, we calculated the frequency at which each cognitive attribute was given priority 1 , $2,3,4$, or 5 (i.e., number of interviews, $n$, per spatial archetype) using Eq. 1.

$$
\text { Priority Score }=\frac{\sum P_{i}}{n}
$$

The Priority Score, after normalization and scaling to zero mean and unit variance, is a dimensionless score ranging from -1 to
+1 , which indicates the priority level of each attribute compared to the average. Below-average values (i.e., negative values) of the Priority Score for an attribute imply that this cognitive attribute is perceived as less of a priority than other spatial archetypes in Uganda. For example, if the Priority Score for the attribute "land fragmentation" in a spatial archetype is positive, it means that stakeholders perceive land fragmentation with higher priority than in other areas of the country. The Priority Score is then compared with the "farm size" spatial archetype data to check whether it is larger or smaller than in other spatial archetypes. If normalized farm size is lower than the average, there is agreement between cognitive and spatial attributes, which means that stakeholders perceive land fragmentation as a priority in a spatial archetype where farm size is indeed smaller than in other parts of Uganda.

\section{RESULTS}

\section{Cognitive archetypes of barriers for sustainable land and water management implementation}

The following cognitive archetypes, built on stakeholders' perceptions, reveal different barriers to scaling SLWM in Uganda (Fig. 4). 
Fig. 4. Cognitive archetypes of barriers for sustainable land and water management adoption. The color gradation indicates the level of priority, with dark red (1) highest and yellow (5) lowest, as expressed by interviewees.

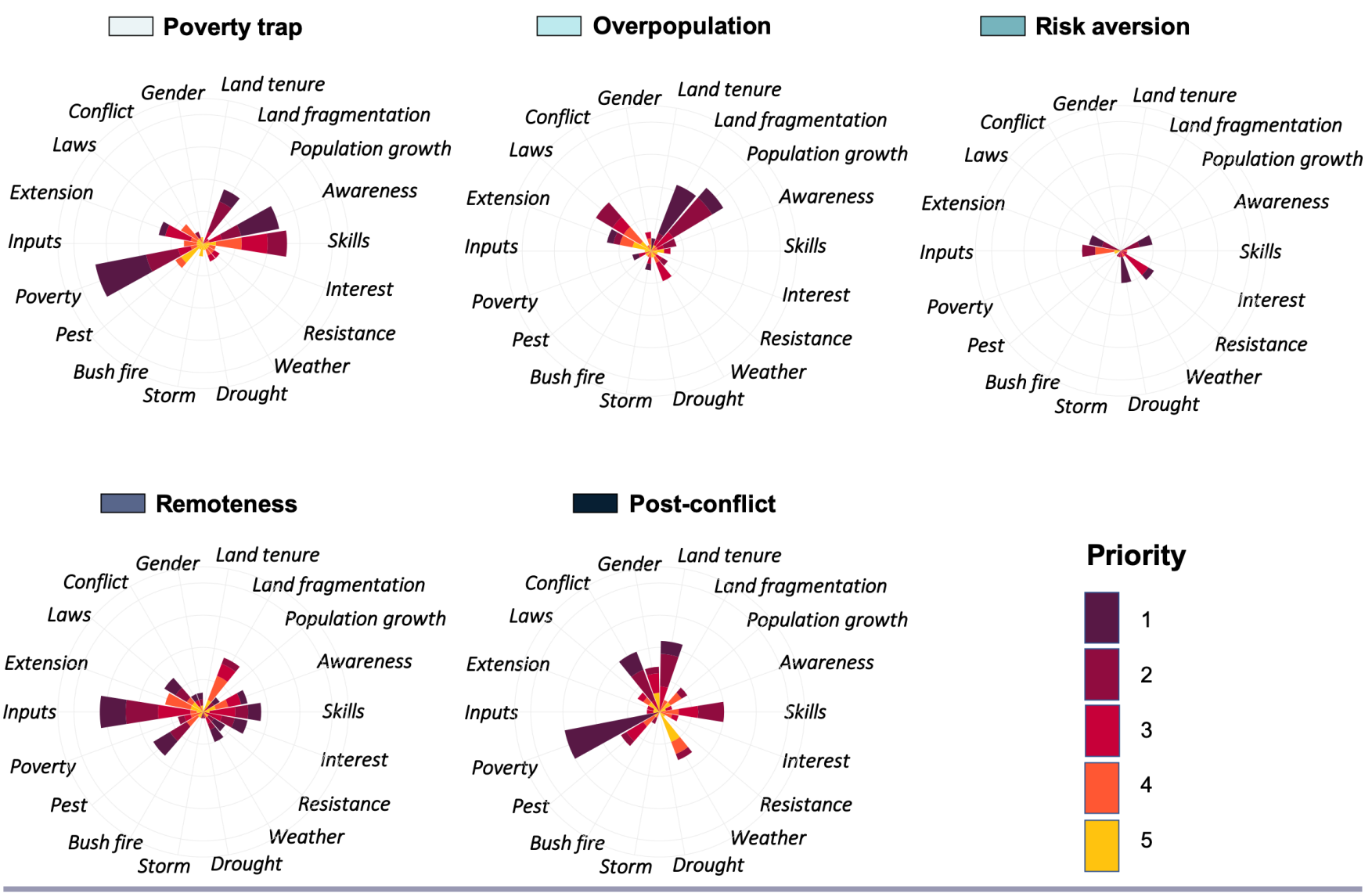

- Poverty trap: A combination of land fragmentation and inadequate farming skills yields low crop productivity, keeping farmers in poverty. Although farmers would benefit from the implementation of SLWM, they lack resources and awareness of SLWM, often driven by ineffective extension services.

- Overpopulation: Rapid population growth has caused deforestation, triggering land degradation and fragmentation due to the traditional land inheritance system. Usually, local legislation prescribes the implementation of SLWM to prevent soil erosion and land degradation. However, the implementation and scaling up is hindered by lack of awareness, weak enforcement, and ineffective support from extension services.

- Risk aversion: The lack of SLWM adoption is explained by a combination of external factors such as lack of inputs (e.g., tools, seedlings, manure, etc.), ineffective extension, and droughts, which make farmers opt for risk diversification strategies other than SLWM to improve their livelihood.

- Remoteness: Small and remote agricultural plots, often located on slopes, where suitable SLWM measures may require large space, long implementation time, and inputs (e.g., trenches covering up to $40 \%$ of the farmland), create unfavorable conditions. These conditions discourage farmers from adopting SLWM.

- Post-conflict: After a prolonged armed conflict and farming inactivity, the rigid patriarchal society and customary land tenure system prevent individual initiatives to adopt innovative SLWM practices, keeping farmers in poverty.

Spatial archetypes of barriers for sustainable land and water management implementation

Seven spatial archetypes were identified from the clustering of districts' spatial attributes, representing the geographical distribution of similar social-ecological characteristics and barriers to SLWM implementation within Uganda (Fig. 5).

- Small farms on steep lands: This archetype comprises highland systems with mean temperature below the country's average, very small average farm size, and lower rural poverty conditions and higher access to credit relative to the national average. It covers most of southwestern Uganda, three mountainous districts in the east around Mount Egon, and the Nebbi district in the northwest.

- Small semi-commercial farms: This archetype comprises the districts of central Uganda in the proximity of Lake Victoria. In relation to national averages, it presents a more humid climate and wealthier socioeconomic conditions, 
Fig. 5. Spatial archetypes of barriers to sustainable land and water management adoption in Uganda. The map shows the geographical locations of the spatial archetypes, and the box plots show the dimensionless (normalized and scaled at the national level) ranges of the 13 spatial attributes characterizing social-ecological barriers. A value of zero for an attribute (vertical red lines) indicates that the attribute is simlar to the mean value for Uganda, whereas positive and negative values reflect values greater and less than the national average, respectively. Districts in grey were excluded from the analysis.

Farm in drier lowlands

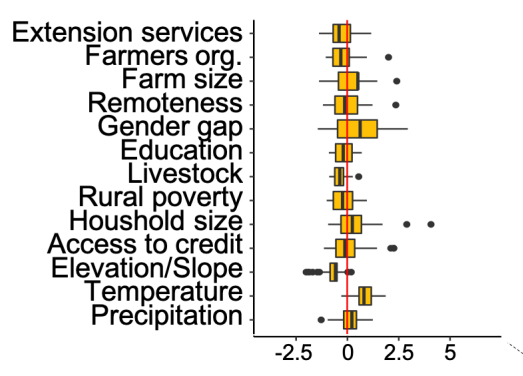

Small farms on steep land

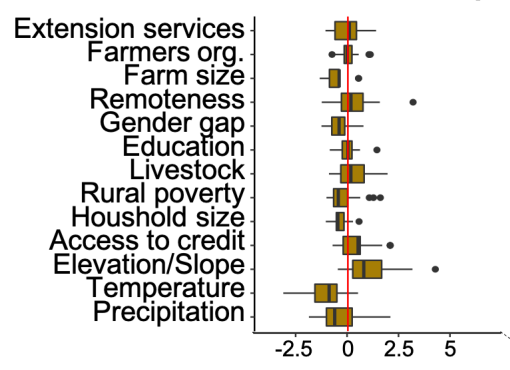

Organized farms

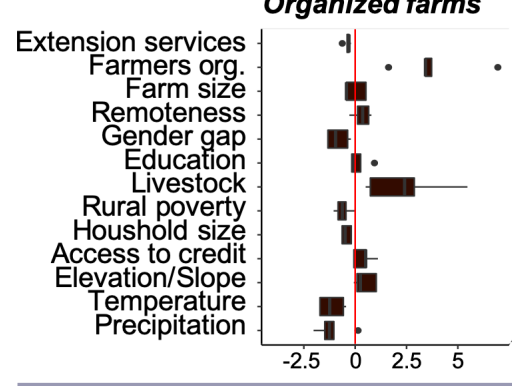

including higher connectivity to cities, lower rural poverty, lower gender imbalance, higher education, and higher degree of market integration.

- Farms in drier lowlands: This is the largest spatial archetype, characterized by a drier climate, lower education, larger gender gap, and poorer farmer support (i.e., low extension service coverage and few farmer organizations) compared to the national average.

- Large supported farms: This archetype is located in the north and, apart from sharing characteristics of farms in drier lowlands, it is characterized by larger farms, as well as the highest extension service coverage and greatest gender gap of all archetypes.

- Poorest small farms: This archetype is characterized by similar social-ecological conditions as small semicommercial farms, but with the highest poverty in Uganda and slightly lower socio-cultural attribute scores (e.g., education and gender gap).
- Organized farms: Spatially surrounded by the small farms on steep lands archetype, organized farms shares similar scores with small farms on steep lands for most attributes, apart from having the highest number of farmer organizations and greatest livestock availability.

- Farms in remote drylands: This archetype covers the northeastern part of Uganda, characterized by remote areas with the driest climate in the country, and lower education and access to credit and poorer agricultural services (i.e., poor extension services and few farmers organizations) compared to the national average.

Combined cognitive and spatial archetypes of barriers to sustainable land and water management adoption

The interviews that were conducted to determine cognitive archetypes were located in only four of the seven spatial archetypes: small farms on steep lands, small semi-commercial farms, farms in drier lowlands, and large supported farms. By combining the cognitive archetypes with these four spatial 
Fig. 6. Combined cognitive and spatial archetypes. Bar plots show the distribution of the five cognitive archetypes (number of interviews on the vertical axes) on the four spatial archetypes hosting interviews. The most relevant cognitive archetypes in a region are in red font, the second most relevant ones are in black, and the least relevant ones are in gray font. Interview locations are shown as colored dots on the map. Grey districts $=$ the three spatial archetypes that did not host interviews.

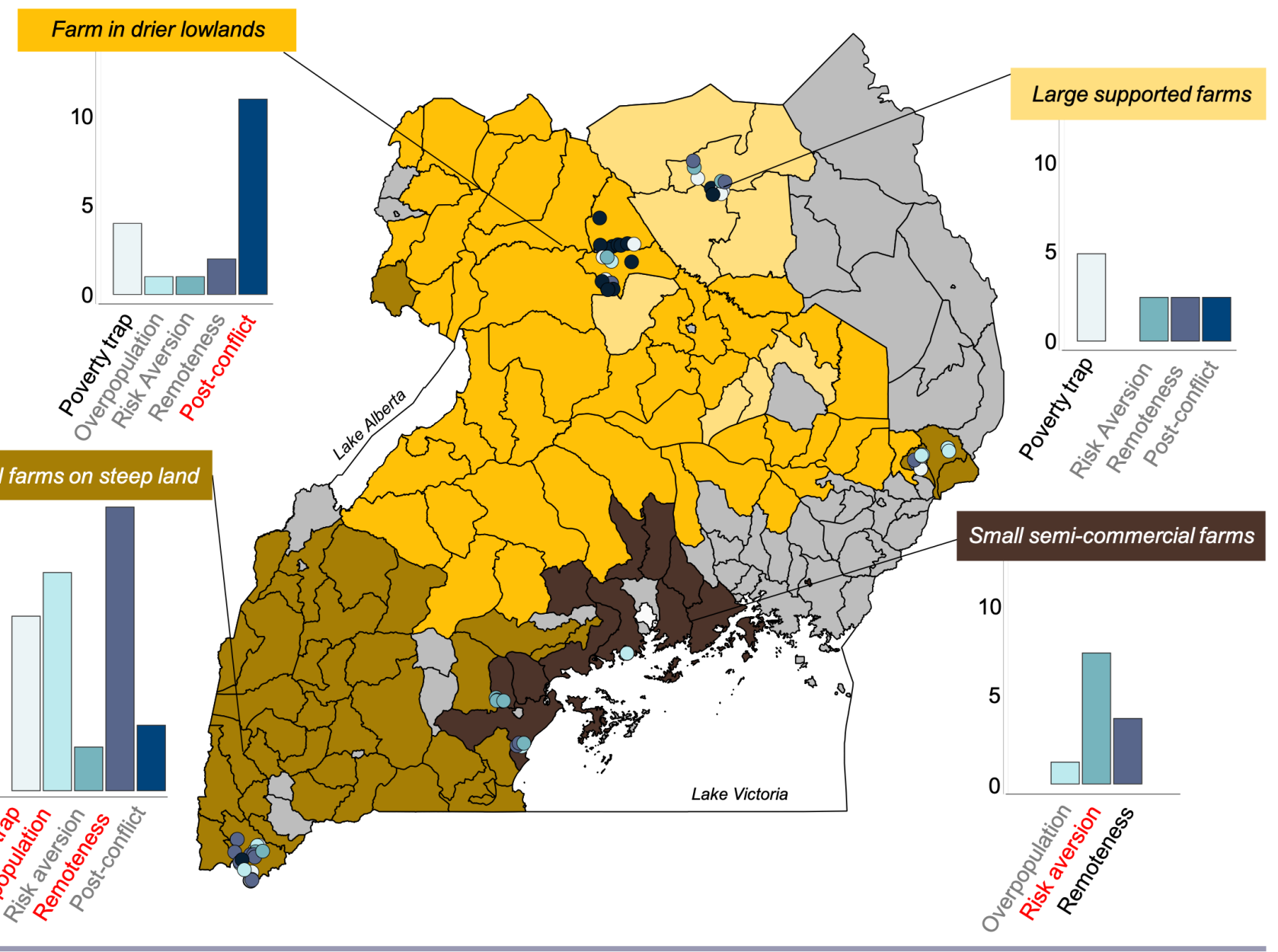

archetypes, we can determine the relative importance of the cognitive archetypes in different contexts of Uganda and draw a more holistic picture of the situations around barriers entailing both people's motivations and the social-ecological contexts (Fig. $6)$.

Small farms on steep lands is the spatial archetype with the highest diversity of cognitive archetypes, with three dominant cognitive archetypes. Nevertheless, $>85 \%$ of the barriers, as perceived by stakeholders, reflect remoteness, overpopulation, and poverty trap. The pressures posed on natural resources by population growth and abundant precipitation have vastly increased soil erosion. Typical measures identified by interviewees in this spatial archetype are soil erosion mitigation practices (e.g., trenches, terraces, and soil and water conservation; Fig. A1.1).

Similar SLWM practices are adopted in the small semicommercial farms archetype with the same aim of soil erosion reduction. Additionally, given the higher market integration, intercropping is used to grow cash crops together with staple crops to optimize the use of space in small farm plots (for example, banana trees offer shade to coffee plants), and water harvesting provides additional irrigation and boosts production. In this spatial archetype, six of ten interviewees fall within the dynamics of farmer resistance. In a context of higher market integration and lower poverty rates, farmers have generally higher access to inputs and credit. Thus, the remaining barriers are the low awareness of isolated farmers (e.g., those not part of farmer organizations) and the limited resources of extension workers (both capacity and knowledge).

In the country's north, which harbors farms in drier lowlands and large supported farms archetypes, the dominant SLWM practices are mulching, intercropping, zero grazing, and agroforestry, which are generally used to decrease soil-water evaporation and increase soil fertility to build productive agricultural systems and improve the poverty conditions that are particularly severe in these areas. This set of practices is mirrored by the distribution of practices shown by the post-conflict cognitive archetype, which is the dominant one (covering $60 \%$ of interviewees) in the farms in drier lowlands spatial archetype. No dominant cognitive archetype can exhaustively explain the barriers for SLWM 
implementation on large supported farms, although poverty trap has the highest representation, with four of ten interviewees.

Results of comparison between cognitive and spatial attributes To provide an indication of the generalizability of cognitive archetypes within the spatial archetypes, we checked the agreement of comparable attributes between cognitive (Priority Score) and spatial data (Fig. 7). The complete results are available in Fig. A1.2.

Fig. 7. Match between spatial data and stakeholders' perceptions. Rectangles show agreement (white) and disagreement (dashed) between district data (averaged at spatial cluster level) and the Priority Score (from stakeholders' perceptions) within the four spatial archetypes. The two sets of data agree when both exhibit conditions higher (upward arrow) or lower (downward arrow) than the national average, otherwise they disagree. The five spatial attributes are the common ones between spatial and cognitive archetypes.

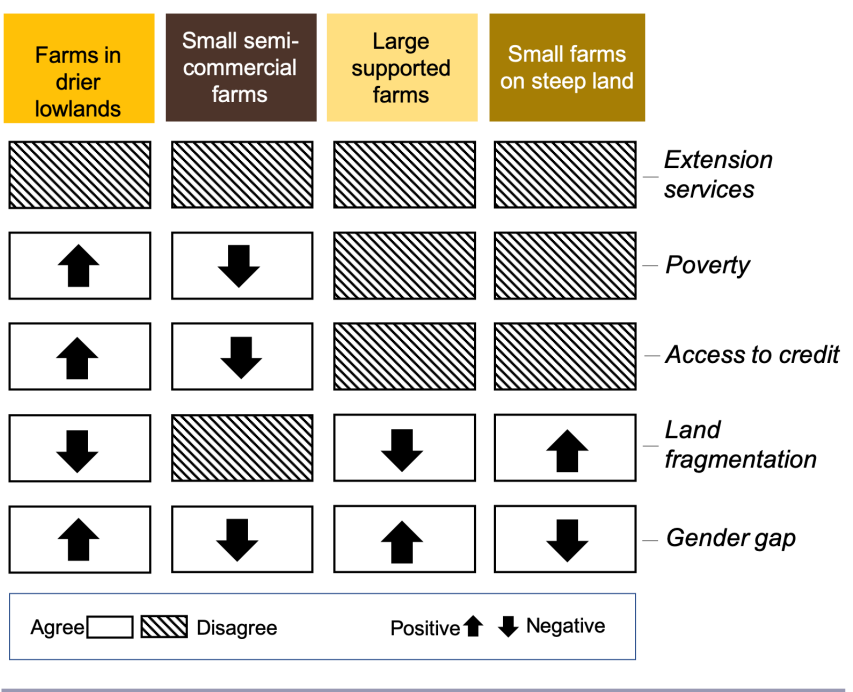

The gender gap attribute had the highest agreement between the two data sets, meaning that gender inequality is perceived as a higher priority barrier in spatial archetypes with higher gender inequality (compared to the national average), whereas it is considered a less urgent barrier in spatial archetypes with lower gender inequality. Land fragmentation is the attribute with the second-best agreement between stakeholders' perceptions and spatial data. Land fragmentation is perceived as a barrier in small farms on steep land, which is the spatial archetype with the smallest average farm size, but it is not perceived as a barrier in large supported farms, which has the largest average farm size. Access to credit and poverty show agreement between perception and spatial data in two of the four spatial archetypes. In contrast, extension services shows complete disagreement between stakeholders' perceptions and spatial data.

Regarding the spatial archetypes, farms in drier lowlands and small semi-commercial farms show a greater match between sets of attributes, suggesting that generalizing the barrier dynamics of the cognitive archetypes within these districts might be more reliable than a generalization of cognitive archetypes for the other spatial archetypes. In contrast, large supported farms and small farms on steep lands show only two of five attributes matching, suggesting that perceived barriers have lower representation in spatial data, which make generalizations of cognitive archetypes less reliable.

\section{DISCUSSION}

System perspective on the barriers to scaling sustainable land and water management

The mixed-methods approach presented here contributes to advancing methodological applications of archetypes in various ways. The two forms of archetype are generated through separate analysis, based on different data but similar methodological steps. However, their combination is the strength of this approach, bringing meaning and context to the overall analysis of the barriers to scaling SLWM. Meaning is provided by the cognitive archetypes, which are designed to capture recurrent perception of stakeholders and describe different dynamics of barriers. Context is given by the spatial archetypes, which are designed to capture spatial similarities in social-ecological conditions.

A first contribution of this work is to show how spatial archetypes can be used operationally to transfer insights within similar socialecological contexts, as indicated by other scholars but rarely implemented (Václavík et al. 2016, Sietz et al. 2017, Rocha et al. 2020). We identify the cognitive archetypes that are most relevant in each social-ecological context (i.e., spatial archetype), which provide concrete boundaries when generalizing specific dynamics. In some cases, there are distinctive cognitives archetypes explaining the barriers to scaling SLWM, e.g., the post-conflict cognitive archetype in farms in drier lowlands. In other cases, the generalizability is less straightforward, with multiple relevant mechanisms within a spatial archetype. The case of small farms on steep land, with three dominant cognitive archetypes, is emblematic. This finding reveals that even areas with similar social-ecological patterns present different mechanisms of barriers. As predictable as it might seem in a complex context, this approach provides additional diagnostic tools to the current use of spatial archetypes, which usually assumes that mapping social-ecological patterns can isolate social-ecological dynamics, considering social-ecological systems as "units in which distinctive human-environment interactions take place" (Hamann et al. 2015). In contexts of data scarcity or large-scale assessments, spatial social-ecological archetypes can provide a useful first approximation of social-ecological dynamics (Václavík et al. 2013, Rocha et al. 2020), but with further use of perception data, as shown here, cognitive archetypes can be used as building blocks to provide an additional layer of detail in explaining complex social-ecological dynamics.

\section{Generalizability and limitations}

Another key contribution of the mixed-methods approach is the cross-comparison of attributes between cognitive and spatial archetypes. This process helps to understand how representative the cognitive archetypes are for the spatial archetypes and provides a measure of reliability for generalization purposes.

Our results show that stakeholders' perceptions of the gender gap and land fragmentation adequately reflect the spatial distribution of district data across spatial archetypes. This situation is not the case for poverty and access to credit, which show partial 
mismatches in the archetypes of small farms on steep land and large supported farms, indicating the potential unreliability of generalizing cognitive archetypes in these spatial archetypes. In contrast, the spatial archetypes of farms in drier lowlands and small semi-commercial farms show predominant agreement between types of attributes, suggesting more reliable generalizability.

A special case is represented by extension services, which shows complete disagreement between spatial and perception data. In this case, given the slightly different nature of the attribute that refers to extension coverage for the spatial data and extension quality for the perception data, the mismatch might not necessary imply unfit or biased data, but rather reveals additional nuances. For example, the large supported farms archetype is characterized by the highest coverage of extension services, with approximately $50 \%$ of the families declaring that they have received assistance from extension workers. Nevertheless, the stakeholders claim that ineffective extension services are one of the priority barriers for SLWM implementation in this region. This mismatch suggests that there is no correlation between spatial coverage and quality of extension services, although $50 \%$ is a relatively low level of extension coverage compared to other sub-Saharan African countries (Chianu and Tsujii 2004). This mismatch shows that the spatial archetypes alone would not be sufficient to interpret the importance of improving the quality of extension services, which resonates with previous studies (Benin et al. 2011, Hasan et al. 2013, AfranaaKwapong and Nkonya 2015) and confirms this factor to be a priority for the whole of Uganda.

Although comparing attributes can provide a measure of reliability for generalization across scales, there are some issues related to the different nature of data used and the different scales at which they operate that is worth discussing. Interviews mainly occurred in five regions of Uganda, which were sampled to cover the main macro-regions and were guided by the judgment of local experts consulted during the workshop. However, in cases such as farmers in drier lowlands, the case studies are located in only three adjacent districts within a much larger spatial archetype, which might raise concerns about the transferability of local perceptions to more distant locations. Although each district may have particular conditions and each stakeholder may hold a specific perception, the very purpose of archetype analysis is to apply a consistent set of methods to find a middle-ground level of generalization that can provide usable and pragmatic guidance for solving problems linked to complex social-ecological conditions (Oberlack et al. 2019). In this direction, developing a clear validation procedure represents a generic challenge for archetype analysis (Eisenack et al. 2019), which would further improve the usefulness of the approach.

Another potential source of bias comes from the targeted group of farmers. In fact, we selected only farmers who had successfully adopted SLWM practices. Including farmers who had a negative experience with adoption may have increased the complexity of the analysis and eventually yielded different results, but also potentially affected the readability of the analysis. Moreover, we decided to include only farmers with a complete and consistent experience from the initial adoption phase to the consolidated production phase.
Regional barriers and implications for policies

Considering the different mechanisms acting as barriers to SLWM adoption, specific policies might be put in place in each spatial archetype, especially those with the highest reliability in the analysis. In farms in drier lowlands, citizens were displaced in camps during a long conflict, with no opportunity to continue farming (Bozzoli et al. 2011). This situation affected agricultural and societal development, the latter reflected in the low education and high gender gap of the archetype. In this region, poverty is the dominant barrier, and the population still relies on subsidies (Tusiime et al. 2013). Women, as in the rest of Uganda, are the ones working in the fields, but land ownership and use in this region are controlled by men. This rigid patriarchal customary land system, where decisions are taken by the older man of the clan, often repress the initiative to implement SLWM taken by women in favor of traditional practices. Moreover, the extremely deprived conditions of poverty and the lack of experience and skills caused by the prolonged confinement in internal displacement camps make farmers more inclined to pursue offfarm activities and less inclined to improve their farming practices. The extension service support needed to bridge the lack of knowledge and skills is still weak, and there are few farmer organizations, which together hinder the scaling up of SLWM. Extension workers should be given resources (i.e., fuel, tools, and seedlings) to raise awareness of SLWM and support farmers in the implementation phase.

A completely different situation governs the barriers for small semi-commercial farms, which is the spatial archetype with the best access to markets and best socioeconomic indicators score. This situation is the most favorable for the implementation of SLWM practices, especially because of the proximity to markets, which provides more opportunities for cash crop production and liquidity. However, with better access to market, farmers might also opt for diversified household strategies to compensate the risk of low agricultural productivity with off-farm income (Ellis 1998, Ellis and Freeman 2004). These dynamics, here captured by the "risk aversion" cognitive archetype, represent an underlying factor across all spatial archetypes in Uganda, and also found in other African contexts (Hajdu et al. 2020). This type of farmer's choice might also prove a resilient strategy for local communities (Ellis 1998), although reduced investment in agriculture might lead to land abandonment and further land degradation. In these conditions, strengthening local institutions, such as local farmer organizations, can prove an effective strategy to encourage farmers to continue investing in agriculture and to take advantage of good market conditions (Feder et al. 2010).

In the remaining spatial archetypes, farms in drier lowlands and small farms on steep lands, the high disagreement between perception and spatial data, together with the heterogeneous composition of cognitive archetypes, make the overall interpretation less reliable and policy recommendation less straightforward. For example, despite being located in the region affected by the armed conflict and sharing similar features with farms in drier lowlands, the post-conflict cognitive archetype is marginally represented in large supported farms. Also, despite exhibiting the highest extension service coverage in the whole country, ineffective extension services emerge as a concern for stakeholders (Fig. 7). Again, the coverage and quality of extension services are not necessarily correlated, but the high 
uncertainty in the overall characterization of this spatial archetype make implications for policies unclear.

\section{CONCLUSIONS}

The complex dynamics governing the adoption of SLWM by smallholder farmers can represent an obstacle when planning effective strategies to support the sustainable intensification of agriculture. In our study of Uganda, we have shown how a combination of cognitive and spatial archetypes can help to identify both cross-cutting, such as ineffective extension services, and context-specific interventions to remove existing barriers. While the cognitive archetypes explain five different mechanisms hindering SLWM adoption, the spatial archetypes provide the geographical boundaries to locate these mechanisms. By applying the proposed cross-scale approach to Uganda, we showcase the strength and pinpoint the limitations that can be further developed and replicated for disentangling complex socialecological dynamics in a specific location, thus providing a methodological tool to tailor sustainability policies in a contextsensitive way.

Responses to this article can be read online at: https://www.ecologyandsociety.org/issues/responses. $\mathrm{php} / 12531$

\section{Author Contributions:}

L.P. conceived the presented idea, conducted the data collection (supported by R.K. and J.T.), performed the computations, and wrote the manuscript. S.P. contributed in developing the framing and methodology. F.J and A.T. contributed in conceiving the idea, supervised the findings of this work, and revised the manuscript. All authors discussed the results and contributed to the final manuscript.

\section{Acknowledgments:}

This research was funded by the Swedish Research Council (VR, project 2015-06503) and the Swedish Research Council for Environment, Agricultural Sciences and Spatial Planning FORMAS (942-2015-740). We thank the Bolin Centre for Climate Research for funding the fieldwork that supported the data collection in Uganda.

\section{Data Availability:}

The datalcode that support the findings of this study are openly available in Github at https://github.com/piemonteseluigil Uganda SLWM archetypes. git.

\section{LITERATURE CITED}

Aduwo, O. E., J. O. Aransiola, L. O. Ikuteyijo, O. T. Alao, O. F. Deji, J. O. Ayinde, O. C. Adebooye, and D. J. Oyedele. 2019. Gender differences in agricultural technology adoption in developing countries: a systematic review. Acta Horticulturae 1238:227-238. https://doi.org/10.17660/ActaHortic.2019.1238.24

AfranaaKwapong, N., and E. Nkonya. 2015. Agricultural extension reforms and development in Uganda. Journal of
Agricultural Extension and Rural Development 7(4):122-134. https://doi.org/10.5897/JAERD2013.0528

Ampaire, E. L., P. Happy, P. van Asten, and M. Radeny. 2015. The role of policy in facilitating adoption of climate-smart agriculture in Uganda. CGIAR Research Program on Climate Change, Agriculture and Food Security (CCAFS), Copenhagen, Denmark. [online] URL: https://hdl.handle.net/10568/65143

Anderson, J. R., and G. Feder. 2004. Agricultural extension: good intentions and hard realities. World Bank Research Observer 19 (1):41-60. https://doi.org/10.1093/wbro/lkh013

Banadda, N. 2010. Gaps, barriers and bottlenecks to sustainable land management (SLM) adoption in Uganda. African Journal of Agricultural Research 5(25):3571-3580. https://doi.org/10.5897/ AJAR10.029

Benin, S., E. Nkonya, G. Okecho, J. Randriamamonjy, E. Kato, G. Lubade, and M. Kyotalimye. 2011. Returns to spending on agricultural extension: the case of the National Agricultural Advisory Services (NAADS) program of Uganda. Agricultural Economics 42(2):249-267. https://doi.org/10.1111/j.1574-0862.2010.00512. $\underline{\mathrm{X}}$

Bouma, J. A., S. S. Hegde, and R. Lasage. 2016. Assessing the returns to water harvesting: a meta-analysis. Agricultural Water Management 163:100-109. https://doi.org/10.1016/j.agwat.2015.08.012

Bozzoli, C., T. Brück, and T. Muhumuza. 2011. Activity choices of internally displaced persons and returnees: quantitative survey evidence from post-war northern Uganda. Microcon Research Working Paper 53. Microcon, Brighton, UK. https://dx.doi. org/10.2139/ssrn.1948489

Charrad, M., N. Ghazzali, V. Boiteau, and A. Niknafs. 2014. NbClust: an R package for determining the relevant number of clusters in a data set. Journal of Statistical Software 61(6). http:// dx.doi.org/10.18637/jss.v061.i06

Chianu, J. N., and H. Tsujii. 2004. Missing links in sustainable food production in west Africa: the case of the savannas of northern Nigeria. Sustainable Development 12(4):212-222. https://doi.org/10.1002/sd.238

Conceição, P., S. Levine, M. Lipton, and A. Warren-Rodríguez. 2016. Toward a food secure future: ensuring food security for sustainable human development in sub-Saharan Africa. Food Policy 60:1-9. https://doi.org/10.1016/j.foodpol.2016.02.003

Ebanyat, P., N. de Ridder, A. de Jager, R. J. Delve, M. A. Bekunda, and K. E. Giller. 2010. Drivers of land use change and household determinants of sustainability in smallholder farming systems of Eastern Uganda. Population and Environment 31:474-506. https://doi.org/10.1007/s11111-010-0104-2

Eisenack, K., S. Villamayor-Tomas, G. Epstein, C. Kimmich, N. Magliocca, D. Manuel-Navarrete, C. Oberlack, M. Roggero, and D. Sietz. 2019. Design and quality criteria for archetype analysis. Ecology and Society 24(3):6. https://doi.org/10.5751/ES-10855-240306

Ellis, F. 1998. Household strategies and rural livelihood diversification. Journal of Development Studies 35(1):1-38. https://doi.org/10.1080/00220389808422553 
Ellis, F., and H. A. Freeman. 2004. Rural livelihoods and poverty reduction strategies in four African countries. Journal of Development Studies 40(4):1-30. https://doi.org/10.1080/00220380410001673175

Ellis-Jones, J., and A. Tengberg. 2000. The impact of indigenous soil and water conservation practices on soil productivity: examples from Kenya, Tanzania and Uganda. Land Degradation and Development 11(1):19-36. https://doi.org/10.1002/(SICI) 1099-145X(200001/02)11:1\%3C19::AID-LDR357\%3E3.0.CO;2-2

Feder, G., J. R. Anderson, R. Birner, and K. Deininger. 2010. Promises and realities of community-based agricultural extension. Pages 187-208 in K. Otsuka and K. Kalirajan, editors. Community, market and State in development. Palgrave Macmillan, London, UK. https://doi.org/10.1057/9780230295018_12

Fowler, R., and J. Rockstrom. 2001. Conservation tillage for sustainable agriculture: An agrarian revolution gathers momentum in Africa. Soil and Tillage Research 61(1):93-108. https://doi.org/10.1016/S0167-1987(01)00181-7

Global Administrative Areas. 2012. Global administrative areas (boundaries). [digital geospatial data]. University of California, Berkely, California, USA. [online] URL: https://gadm.org/

Hajdu, F., D. Neves, and S. Granlund. 2020. Changing livelihoods in rural Eastern Cape, South Africa (2002-2016): diminishing employment and expanding social protection. Journal of Southern African Studies 46(4):743-772. https://doi. org/10.1080/03057070.2020.1773721

Hamann, M., R. Biggs, and B. Reyers. 2015. Mapping socialecological systems: identifying 'green-loop' and 'red-loop' dynamics based on characteristic bundles of ecosystem service use. Global Environmental Change 34:218-226. https://doi. org/10.1016/j.gloenvcha.2015.07.008

Hart, T., and J. Mouton. 2005. Indigenous knowledge and its relevance for agriculture: a case study in Uganda. Indilinga: African Journal of Indigenous Knowledge Systems 4(1):249-263. [online] URL: https://www.ajol.info/index.php/indilinga/article/ view/26378

Hasan, M. F., K. S. Imai, and T. Sato. 2013. Impacts of agricultural extension on crop productivity, poverty and vulnerability: evidence from Uganda. Discussion Paper Series DP2012-34. Research Institute for Economics and Business Administration, Kobe University, Kobe, Japan. [online] URL: https://www.rieb.kobe-u.ac.jp/academic/ra/dp/English/DP2012-34. pdf

Hirschman, E. C. 1986. Humanistic inquiry in marketing research: philosophy, method, and criteria. Journal of Marketing Research 23(3):237-249. https://doi.org/10.1177/002224378602300304

Howie, C. 2008. Where the land is greener: case studies and analysis of soil and water conservation initiatives worldwide, edited by H. Liniger and W. Critchley. WOCAT, Switzerland, 2007. ISBN 978929081339 2, xi + 364 pp. Land Degradation and Development 19(4):465-466. https://doi.org/10.1002/ldr.827

Janssen, P., C. Walther, and M. K. B. Lüdeke. 2012. Cluster analysis to understand socio-ecological systems: a guideline. PIK
Report 126. Potsdam Institute for Climate Impact Research (PIK), Potsdam, Germany. [online] URL: https://www.pikpotsdam.de/en/output/publications/pikreports/summary-reportno. -126

Karrasch, L., T. Klenke, and M. Kleyer. 2019. Land-use elements and attributed ecosystem services: an archetype approach to landuse evaluation at the German North Sea coast. Ecology and Society 24(2):13. https://doi.org/10.5751/ES-10744-240213

Kassie, M., B. Shiferaw, and G. Muricho. 2011. Agricultural technology, crop income, and poverty alleviation in Uganda. World Development 39(10):1784-1795. https://doi.org/10.1016/j. worlddev.2011.04.023

Liniger, H., R. M. Studer, C. Hauert, and M. Gurtner. 2011. Sustainable land management in practice: guidelines and best practices for sub-Saharan Africa: field application. TerrAfrica, World Overview of Conservation Approaches and Technologies (WOCAT), and Food and Agriculture Organization, Rome, Italy. [online] URL: http://www.fao.org/3/i1861e/i1861e.pdf

Mugisha, J., and S. Alobo. 2012. Determinants of land management practices in the agricultural highlands of Uganda: a case of Kabale Highlands in Western Uganda. Pages 923-938 in Ruforum third biennial conference, Entebbe, Uganda, 24-28 September 2012. Ruforum, Kampala, Uganda. [online] URL: https://www.ruforum.org/system/tdf/Mugisha $\% 2 \mathrm{C} \% 20 \mathrm{~J} . \% 20 \% 26 \%$ $\underline{20}$

Alobo $\% 2 \mathrm{C} \% 20$ S. .pdf?file $=1 \&$ type $=$ node $\&$ id $=32323 \&$ force $=$

Mwangi, M., and S. Kariuki. 2015. Factors determining adoption of new agricultural technology by smallholder farmers in developing countries. Journal of Economics and Sustainable Development 6(5):208-216. [online] URL: https://www.iiste.org/ Journals/index.php/JEDS/article/view/20710

Nkonya, E. 2002. Soil conservation practices and nonagricultural land use in the south western highlands of Uganda. International Food Policy Research Institute, Washington, D.C., USA. [online] URL: https://pdf.usaid.gov/pdf_docs/Pnacy474. pdf

Ntale, H. K., D. N. Naturinda, M. H. Rubarenzya, and K. Kyamugambi. 2005. The rainwater harvesting strategy for Uganda. Pages 295-299 in S. Kayaga, editor. Maximising the benefits from water and environmental sanitation: Proceedings of the 31st WEDC International Conference, Kampala, Uganda, 31 October-4 November 2005. Water, Engineering and Development Centre, Loughborough University, Loughborough, UK. [online] URL: https://repository.lboro.ac.uk/articles/ conference contribution/The rainwater harvesting strategy for Uganda/9589577

Oberlack, C., D. Sietz, E. Bürgi Bonanomi, A. de Bremond, J. Dell'Angelo, K. Eisenack, E. C. Ellis, G. Epstein, M. Giger, A. Heinimann, C. Kimmich, M. T. J. Kok, D. Manuel-Navarrete, P. Messerli, P. Meyfroidt, T. Václavík, and S. Villamayor-Tomas. 2019. Archetype analysis in sustainability research: meanings, motivations, and evidence-based policy making. Ecology and Society 24(2):26. https://doi.org/10.5751/ES-10747-240226

Pérez-Escamilla, R. 2017. Food security and the 2015-2030 sustainable development goals: from human to planetary health: 
perspectives and opinions. Current Developments in Nutrition 1 (7):e000513. https://doi.org/10.3945/cdn.117.000513

Piemontese, L., G. Castelli, I. Fetzer, J. Barron, H. Liniger, N. Harari, E. Bresci, and F. Jaramillo. 2020. Estimating the global potential of water harvesting from successful case studies. Global Environmental Change 63:102121. https://doi.org/10.1016/j. gloenvcha.2020.102121

Piemontese, L., I. Fetzer, J. Rockström, and F. Jaramillo. 2019. Future hydroclimatic impacts on Africa: beyond the Paris Agreement. Earth's Future 7(7):748-761. https://doi. org/10.1029/2019EF001169

Pimentel, D. 2006. Soil erosion: a food and environmental threat. Environment, Development and Sustainability 8:119-137. https:// doi.org/10.1007/s10668-005-1262-8

Pretty, J. 1999. Can sustainable agriculture feed Africa? New evidence on progress, processes and impacts. Environment, Development and Sustainability 1:253-274. https://doi. org/10.1023/A:1010039224868

Ricotta, C., and J. Podani. 2017. On some properties of the BrayCurtis dissimilarity and their ecological meaning. Ecological Complexity 31:201-205. https://doi.org/10.1016/j.ecocom.2017.07.003

Rocha, J., K. Malmborg, L. Gordon, K. Brauman, and F. DeClerck. 2020. Mapping social-ecological systems archetypes. Environmental Research Letters 15(3):034017. https://doi. org/10.1088/1748-9326/ab666e

Schatzman, L., and A. L. Strauss. 1973. Field research: strategies for a natural sociology. Prentice-Hall, Englewood Cliffs, New Jersey, USA.

Sietz, D., U. Frey, M. Roggero, Y. Gong, N. Magliocca, R. Tan, P. Janssen, and T. Václavík. 2019. Archetype analysis in sustainability research: methodological portfolio and analytical frontiers. Ecology and Society 24(3):34. https://doi.org/10.5751/ ES-11103-240334

Sietz, D., J. C. Ordoñez, M. T. J. Kok, P. Janssen, H. B. M. Hilderink, P. Tittonell, and H. Van Dijk. 2017. Nested archetypes of vulnerability in African drylands: Where lies potential for sustainable agricultural intensification? Environmental Research Letters 12(9):095006. https://doi.org/10.1088/1748-9326/aa768b

Sietz, D., and H. Van Dijk. 2015. Land-based adaptation to global change: What drives soil and water conservation in western Africa? Global Environmental Change 33:131-141. https://doi. org/10.1016/j.gloenvcha.2015.05.001

Spradley, J. P. 2016. Participant observation. Waveland Press, Long Grove, Illinois, USA.

Tengberg, A., and S. Valencia. 2018. Integrated approaches to natural resources management-theory and practice. Land Degradation and Development 29(6):1845-1857. https://doi. org/10.1002/ldr.2946

Thomas, R., M. Reed, K. Clifton, N. Appadurai, A. Mills, C. Zucca, E. Kodsi, J. Sircely, F. Haddad, C. Hagen, E. Mapedza, K. Woldearegay, K. Shalander, M. Bellon, Q. Le, S. Mabikke, S. Alexander, S. Leu, S. Schlingloff, T. Lala-Pritchard, V. Mares, and R. Quiroz. 2018. A framework for scaling sustainable land management options. Land Degradation and Development 29 (10):3272-3284. https://doi.org/10.1002/ldr.3080

Tusiime, H. A., R. Renard, and L. Smets. 2013. Food aid and household food security in a conflict situation: empirical evidence from Northern Uganda. Food Policy 43:14-22. https://doi. org/10.1016/j.foodpol.2013.07.005

Václavík, T., F. Langerwisch, M. Cotter, J. Fick, I. Häuser, S. Hotes, J. Kamp, J. Settele, J. H. Spangenberg, and R. Seppelt. 2016. Investigating potential transferability of place-based research in land system science. Environmental Research Letters 11(9):095002. https://doi.org/10.1088/1748-9326/11/9/095002

Václavík, T., S. Lautenbach, T. Kuemmerle, and R. Seppelt. 2013. Mapping global land system archetypes. Global Environmental Change 23(6):1637-1647. https://doi.org/10.1016/j.gloenvcha.2013.09.004

Wani, S. P., J. Rockström, and T. Oweis, editors. 2009. Rainfed agriculture: unlocking the potential. CABI, Wallingford, UK. https://doi.org/10.1079/9781845933890.0000

Ward, J. H. Jr. 1963. Hierarchical grouping to optimize an objective function. Journal of the American Statistical Association 58(301):236-244. https://doi.org/10.1080/01621459.1963.10500845

Wigboldus, S., L. Klerkx, C. Leeuwis, M. Schut, S. Muilerman, and H. Jochemsen. 2016. Systemic perspectives on scaling agricultural innovations. A review. Agronomy for Sustainable Development 36:46. https://doi.org/10.1007/s13593-016-0380-Z

World Overview of Conservation Approaches and Technologies (WOCAT). 2019. WOCAT global database on sustainable land management. Centre for Development and Environment, Bern, Switzerland. [online] URL: https://qcat.wocat.net/en/wocat/

Zika, M., and K.-H. Erb. 2009. The global loss of net primary production resulting from human-induced soil degradation in drylands. Ecological Economics 69(2):310-318. https://doi. org/10.1016/j.ecolecon.2009.06.014 
Appendix 1: Supplementary material for "Unpacking the barriers to adoption of sustainable land and water management in Uganda"

Table A1.1. List of factors associated to adoption of agricultural innovations in Uganda from metaanalysis. In green are the factors selected as attributes for the analysis and in orange the factors that are included as proxies in some of the selected attributes (e.g. the factor "land size" was selected as spatial attribute, but it also represents a proxy of farm size (Prestele Reinhard et al., 2018)).

\begin{tabular}{|c|c|}
\hline FACTOR & PAPERS $(n=24)$ \\
\hline Education & 8 \\
\hline Labour & 7 \\
\hline Access to credit & 6 \\
\hline Age & 6 \\
\hline Off-farm income & 5 \\
\hline Extension services & 5 \\
\hline Gender & 5 \\
\hline Farm size & 4 \\
\hline Houshold size & 4 \\
\hline Land size & 4 \\
\hline Livestock units & 4 \\
\hline Land tenure & 4 \\
\hline Farmer associations & 3 \\
\hline Distance to Market & 3 \\
\hline Distance farm-house & 3 \\
\hline Land ownership & 3 \\
\hline Slope/location & 3 \\
\hline Clear policy and legal framework & 2 \\
\hline Subsidy provision & 2 \\
\hline Security of land tenure & 2 \\
\hline Agro-climatic conditions & 2 \\
\hline Transport & 2 \\
\hline Training & 2 \\
\hline Lack of government support & 1 \\
\hline Drastic seasonal variability & 1 \\
\hline High investment costs & 1 \\
\hline On-farm income & 1 \\
\hline Information & 1 \\
\hline Capital & 1 \\
\hline Decision making power & 1 \\
\hline Norms and beliefs & 1 \\
\hline Value of output & 1 \\
\hline Fragmented land & 1 \\
\hline Drought/rainfall & 1 \\
\hline Marketing facilities & 1 \\
\hline
\end{tabular}


Cash

Naighbouring SWC 1

Soil fertitily 1

Radio/communication 1

Crop type 1

Crop diversity 1

Crop production 1

Agricultural and environmental related programs $\quad 1$

Land degradation 1

Roads 1

Table A1.2. Spatial attributes and corresponding datasets used for the classification of spatial archetypes of social-ecological barriers in Uganda.

\begin{tabular}{|c|c|c|}
\hline Attribute & Description & Source \\
\hline Precipitation & $\begin{array}{l}\text { Total precipitation }\left(\mathrm{mm} y^{-1}\right) \\
\text { averaged for the period 1986-2016 } \\
\text { from monthly time series data. }\end{array}$ & (Goodman et al., 2019) \\
\hline Elevation & Elevation from sea level (m) & (Goodman et al., 2019) \\
\hline Temperature & Air temperature $(\mathrm{C})$, yearly average & (Goodman et al., 2019) \\
\hline Education & Average education attainment & (Graetz et al., 2018) \\
\hline Gender gap & $\begin{array}{l}\text { Gap in education attainment } \\
\text { between genders measured in years. }\end{array}$ & Derived from Graetz et al. (2018) \\
\hline Remoteness & $\begin{array}{l}\text { Accessibility to cities (with more } \\
\text { than } 50.000 \text { people) in minutes. }\end{array}$ & (Weiss et al., 2018) \\
\hline Household size & $\begin{array}{l}\text { Average household size (number of } \\
\text { people). }\end{array}$ & $\begin{array}{l}\text { (Uganda Bureau of Statistics } \\
\text { (UBOS), 2010) }\end{array}$ \\
\hline Rural poverty & $\begin{array}{l}\text { Poverty density, computed as } \\
\text { number of people in rural areas } \\
\text { living below the national rural } \\
\text { poverty line per square kilometer. }\end{array}$ & (Poverty GIS Database, 2008) \\
\hline Livestock & $\begin{array}{l}\text { Total Tropical Livestock Unit } \\
(\mathrm{TLU})\end{array}$ & $\begin{array}{l}\text { (Africa Ruminants Tropical } \\
\text { Livestock Units (TLU), 2015) }\end{array}$ \\
\hline Farmers'organizations & $\begin{array}{l}\text { Desity of farmers organizations, } \\
\text { computed as number of FO per } \\
\text { hinabitant. }\end{array}$ & $\begin{array}{l}\text { (Farmers' organization of Uganda, } \\
\text { 2017) }\end{array}$ \\
\hline Farm size & Median Landholdings of households & $\begin{array}{l}\text { (The National Livestock Census } \\
\text { Report, 2008) }\end{array}$ \\
\hline
\end{tabular}




\begin{tabular}{l|ll} 
Access to credit & $\begin{array}{l}\text { Percent of agricultural households } \\
\text { reporting having access to credit }\end{array}$ & $\begin{array}{l}\text { (Uganda Bureau of Statistics } \\
\text { (UBOS), 2010) }\end{array}$ \\
Extension services & $\begin{array}{l}\text { Percent of agricultural households } \\
\text { that reported receiving extension } \\
\text { services on farm management }\end{array}$ & (UBOS), 2010)
\end{tabular}

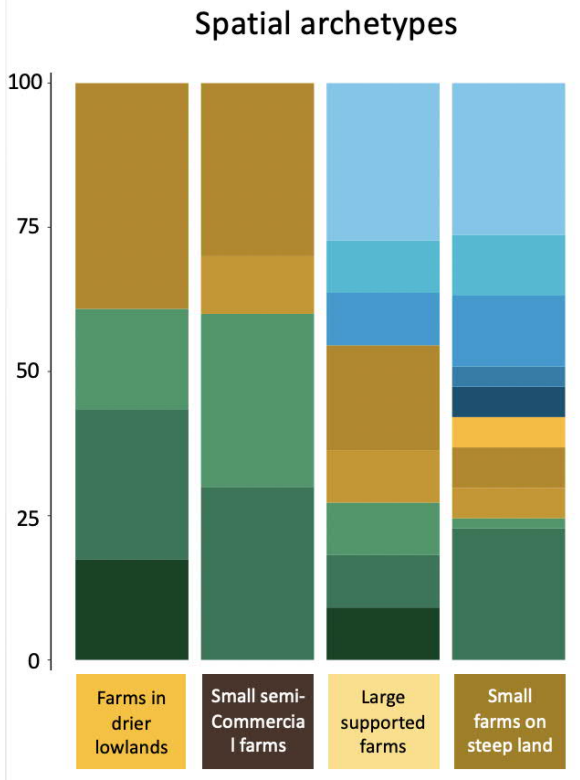

Cognitive archetypes
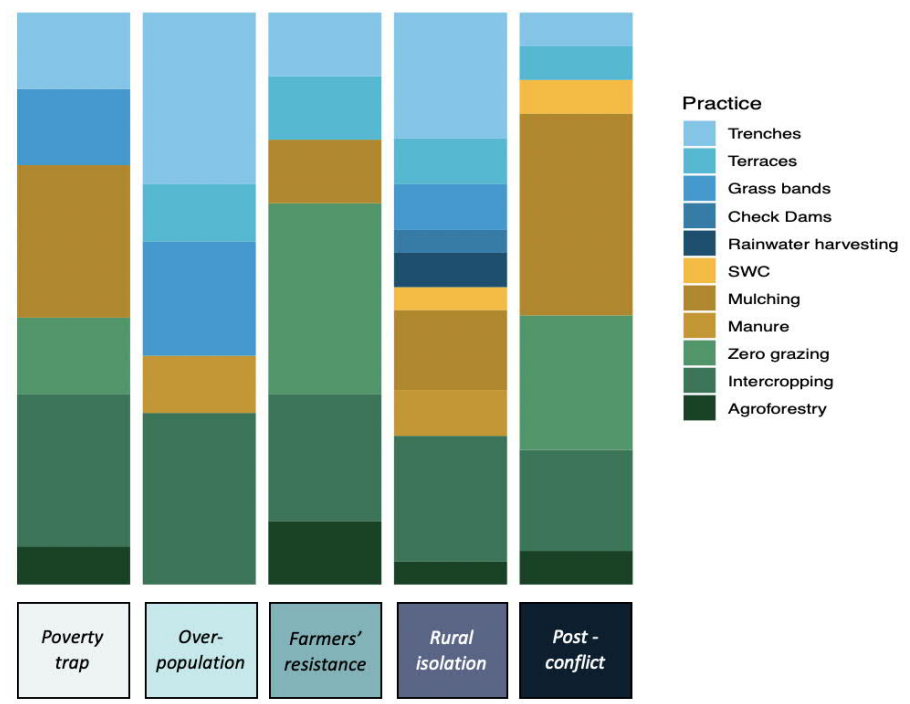

Figure A1.1. Distribution of sustainable land and water management (SLWM) practices across four spatial and five cognitive archetypes in Uganda. The practices are color-coded according to their purposes: soil erosion reduction (blue shades), soil rehabilitation (yellow shades) and increased productivity (green shades). The information on the practices was recorded during the interviews. 


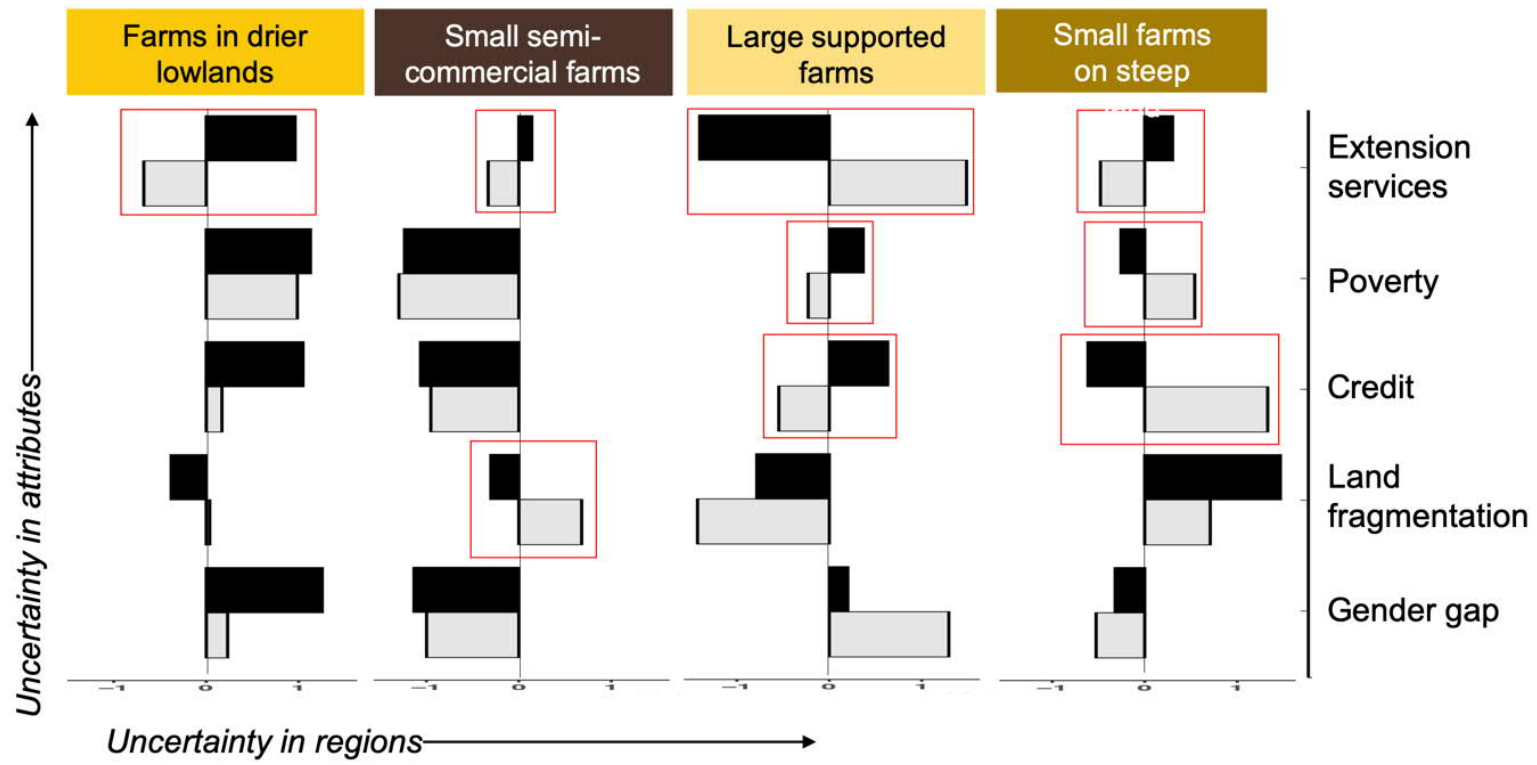

Spatial data $\square \square$ Priority Score

Disagreement

Figure A1.2. Complete comparison between the Priority Scores and spatial data in the four spatial archetypes hosting interviews. The bars show the relative agreement/disagreement between the two sets of data used to generate cognitive (Priority Score) and spatial (spatial data) archetypes.

Source of data used for the spatial attributesXAfrica Ruminants Tropical Livestock Units (TLU), 2015. . FAO - AGAL, Rome, Italy.

Beck, T., Demirgüç-Kunt, A., 2009. Financial Institutions and Markets Across Countries and over Time: Data and Analysis.

Farmers' organization of Uganda, 2017. . Ministry of Agriculture, Animal Industry and Fisheries and the Agricultural Technology and Agribusiness Advisory Services (ATAAS) Project, Entebbe, Uganda.

Goodman, S., BenYishay, A., Lv, Z., Runfola, D., 2019. GeoQuery: Integrating HPC systems and public web-based geospatial data tools. Comput. Geosci. 122, 103-112. https://doi.org/10.1016/j.cageo.2018.10.009

Graetz, N., Friedman, J., Osgood-Zimmerman, A., Burstein, R., Biehl, M.H., Shields, C., Mosser, J.F., Casey, D.C., Deshpande, A., Earl, L., Reiner, R.C., Ray, S.E., Fullman, N., Levine, A.J., Stubbs, R.W., Mayala, B.K., Longbottom, J., Browne, A.J., Bhatt, S., Weiss, D.J., Gething, P.W., Mokdad, A.H., Lim, S.S., Murray, C.J.L., Gakidou, E., Hay, S.I., 2018. Mapping local variation in educational attainment across Africa. Nature 555, 48-53. https://doi.org/10.1038/nature25761

Poverty GIS Database, 2008. . UGANDA BUREAU OF STATISTICS (UBOS) AND INTERNATIONAL LIVESTOCK RESEARCH INSTITUTE (ILRI), Kampala, Uganda.

Prestele Reinhard, Hirsch Annette L., Davin Edouard L., Seneviratne Sonia I., Verburg Peter H., 2018. A spatially explicit representation of conservation agriculture for application in global change studies. Glob. Change Biol. 0. https://doi.org/10.1111/gcb.14307

The National Livestock Census Report, 2008. . Ministry of Agriculture, Animal Industry \& Fisheries and Uganda Bureau of Statistics.

Uganda Bureau of Statistics (UBOS), 2010. Uganda Census of Agriculture. Uganda Bureau of Statistics (UBOS). 
Weiss, D.J., Nelson, A., Gibson, H.S., Temperley, W., Peedell, S., Lieber, A., Hancher, M., Poyart, E., Belchior, S., Fullman, N., Mappin, B., Dalrymple, U., Rozier, J., Lucas, T.C.D., Howes, R.E., Tusting, L.S., Kang, S.Y., Cameron, E., Bisanzio, D., Battle, K.E., Bhatt, S., Gething, P.W., 2018. A global map of travel time to cities to assess inequalities in accessibility in 2015. Nature 553, 333-336.

https://doi.org/10.1038/nature25181

\section{List of papers used in the meta-analysis for spatial attribute selection}

Abesiga, N.K.C., Musali, K.P., 2002. An Investigation of Soil and Water Conservation Related Problems in the Kigezi Highlands of Uganda. Presented at the 12th ISCO Conference, Beijing.

Aduwo, O.E., Aransiola, J.O., Ikuteyijo, L.O., Alao, O.T., Deji, O.F., Ayinde, J.O., Adebooye, O.C., Oyedele, D.J., 2019. Gender differences in agricultural technology adoption in developing countries: a systematic review. Acta Hortic. 227-238. https://doi.org/10.17660/ActaHortic.2019.1238.24

Ampaire, E.L., Happy, P., van Asten, P., Radeny, M., 2015. The Role of Policy in Facilitating Adoption of Climate-Smart Agriculture in Uganda. CGIAR Research Program on Climate Change, Agriculture and Food Security (CCAFS), Copenhagen, Denmark.

Baguma, D., Loiskandl, W., 2010. Rainwater harvesting technologies and practises in rural Uganda: a case study. Mitig. Adapt. Strateg. Glob. Change 15, 355-369. https://doi.org/10.1007/s11027-010-9223-4

Coromaldi, M., Pallante, G., Savastano, S., 2015. Adoption of modern varieties, farmers' welfare and crop biodiversity: Evidence from Uganda. Ecol. Econ. 119, 346-358. https://doi.org/10.1016/j.ecolecon.2015.09.004

Ebanyat, P., de Ridder, N., de Jager, A., Delve, R.J., Bekunda, M.A., Giller, K.E., 2010. Drivers of land use change and household determinants of sustainability in smallholder farming systems of Eastern Uganda. Popul. Environ. 31, 474-506. https:// doi.org/10.1007/s11111-010-0104-2

Ekepu, D., Tirivanhu, P., Nampala, P., 2017. Assessing farmer involvement in collective action for enhancing the sorghum value chain in Soroti, Uganda. South Afr. J. Agric. Ext. 45, 118-130. https://doi.org/10.17159/2413-3221/2017/v45n1a444

Hisali, E., Birungi, P., Buyinza, F., 2011. Adaptation to climate change in Uganda: Evidence from micro level data. Glob. Environ. Change 21, 1245-1261. https://doi.org/10.1016/ j.gloenvcha.2011.07.005

Kagoya, S., Paudel, K.P., Daniel, N.L., 2018. Awareness and Adoption of Soil and Water Conservation Technologies in a Developing Country: A Case of Nabajuzi Watershed in Central Uganda. Environ. Manage. 61, 188-196. https://doi.org/10.1007/s00267017-0967-4

Kassie, M., Shiferaw, B., Muricho, G., 2011. Agricultural Technology, Crop Income, and Poverty Alleviation in Uganda. World Dev. 39, 1784-1795. https://doi.org/10.1016/j.worlddev.2011.04.023

Katwijukye, A.K., Doppler, W., 2004. The socio-economic analysis of land use changes and soil conservation in central and western Uganda. Uganda J. Agric. Sci. 303-311. https://doi.org/10.1016/j.ecolecon.2015.09.004

Lubwama, F.B., n.d. Socio-economic and gender issues affecting the adoption of conservation tillage practices 6 . 
Mcdonagh, J., Lu, Y., Semalulu, O., 2014. Adoption and adaptation of improved soil management practices in the eastern Ugandan hills. Land Degrad. Dev. 25, 58-70. https://doi.org/10.1002/ldr.1143

Mugagga, F., 2013. Land tenure and soil conservation practices on the slopes of Mt Elgon National Park, Eastern Uganda. J. Geogr. Reg. Plan. 6, 255-262. https://doi.org/10.5897/JGRP2013.0398

Mugisha, J., Alobo, S., 2012. Determinants of Land Management Practices in the Agricultural Highlands of Uganda: A Case of Kabale Highlands in Western Uganda. Presented at the RUFORUM Third Biennial Conference, 24-28, Entebbe, Uganda, pp. 24-28.

Mugonola, B., Deckers, J., Poesen, J., Isabirye, M., Mathijs, E., 2013. Adoption of soil and water conservation technologies in the Rwizi catchment of south western Uganda. Int. J. Agric. Sustain. 11, 264-281. https://doi.org/10.1080/14735903.2012.744906

Mwangi, M., Kariuki, S., 2015. Factors Determining Adoption of New Agricultural Technology by Smallholder Farmers in Developing Countries.

Nabikolo, D., Bashaasha, B., Mangheni, M.N., Majaliwa, J.G.M., 2012. Determinants of climate change adaptation among male and female headed farm households in eastern Uganda. Afr. Crop Sci. J. 20, 203-212-212.

Nadhomi, D.L., Tenywa, J.S., Musali, P., Nakileza, B.R., 2013. Farmers' Perception of Erosion Risk and Its Implication on the Adoption of Soil and Water Conservation Practices. Int. J. Adv. Agric. Sci. Technol. 2, 28-44-44.

Nkonya, E., 2002. Soil conservation practices and non-agricultural land use in the South Western Highlands of Uganda (A Contribution to the Strategic Criteria for Rural Investments in Productivity (SCRIP) Program of the USAID Uganda Mission). The International Food Policy Research Institute (IFPRI), 2033 K Street, N.W. Washington, D.C.

Nkonya, E., Kaizzi, C., Pender, J., 2005. Determinants of nutrient balances in a maize farming system in eastern Uganda. Agric. Syst. 85, 155-182. https://doi.org/10.1016/j.agsy.2004.04.004

Ntale, H.K., Naturinda, D.N., Rubarenzya, M.H., Kyamugambi, K., 2005. The rainwater harvesting strategy for Uganda.

Pender, J., Nkonya, E., Jagger, P., Sserunkuuma, D., Ssali, H., 2004. Strategies to increase agricultural productivity and reduce land degradation: evidence from Uganda. Agric. Econ. 31, 181-195. https://doi.org/10.1111/j.1574-0862.2004.tb00256.x

Turinawe, A., Drake, L., Mugisha, J., 2015. Adoption intensity of soil and water conservation technologies: a case of South Western Uganda. Environ. Dev. Sustain. 17, 711-730. https://doi.org/10.1007/s10668-014-9570-5 